\title{
METHODOLOGY OF JUSTIFICATION THE TYPE AND EVALUATION OF QUALITY GROUP SEARCH OF DEFECTS IN THE REPAIR RADIO-ELECTRONIC MEANS
}

Romanenko V. P. - PhD, Head of Special Department of the Institute for Special Communication and Information Protection of the KPI named after Igor Sikorsky, Kyiv, Ukraine.

Sakovich L. N. - PhD, Associate Professor, Associate Professor of Special department of the Institute of Special Communication and Information Protection of KPI named after Igor Sikorsky, Kyiv, Ukraine.

Ryzhov Y. V. - PhD, Senior Researcher of the Research Laboratory of the Ground Forces Scientific Center of the Hetman Petro Sahaidachnyi National Army Academy, Lviv, Ukraine.

Gnatyuk S. E. - PhD, Head of the Department of the Department of Electronic Communications Development of the State Service for Special Communications and Information Protection, Kyiv, Ukraine.

Rozum I. Y. - PhD, Senior Research Fellow, National Defence University of Ukraine named after Ivan Cherniakhovsky, Kyiv, Ukraine.

\section{ABSTRACT}

Context. Radioelectronic devices are continuously complicated, which complicates the process of restoring their efficiency, when the diagnosis consumes the largest labor costs and time. Therefore, the promising direction of increasing the efficiency of the renewal of modern electronic means is to improve diagnostic support.

Objective. The purpose of the article is to increase the efficiency of diagnostic provision of radio electronic means at the expense of a reasonable choice of the type of group search of defects.

Method. In the work analytical studies of conditional algorithms of diagnosis with the use of graph theory theory, probability theory and the theory of discrete search - a scientific discipline that studies the diagnostic process when restoring the efficiency of complex technical objects with varying degrees of damage through research and optimization of procedures and algorithms for detection of a priori - in unknown number of elements with given properties on the finite structurally-bounded set according to some criterion.

Results. The method of choosing the type of algorithm of group search of defects at given restrictions and assumptions on the criterion of minimum labor costs on the basis of generalization of the graph-analytical model of group search of defects with quantitative estimation of probabilistic, time and cost indicators of the quality of the process of diagnosing radioelectronic devices with different degree of damage, which allows to pre-substantiate the most appropriate algorithm for group defects search for use in the development of diagnostic support for modern radio ectronic means.

Conclusions. For the first time, various types of group search of defects with a quantitative estimation of the efficiency of their use depending on the features of radio-electronic means and the conditions for their restoration of efficiency are considered in a complex way.

KEYWORDS: radio-electronic means, group search of defects, restoration of working capacity, diagnostic support.

\section{ABBREVIATIONS}

GDS is a group defect search;

GDSI is a an independent GDS;

GDSZ is a Zone GDS;

GDSC is a compliant GDS;

GTLP is a group TLP;

DS is a diagnostic support;

TLP is a tree of logical possibilities;

ERE is a electrical radio elements;

$\mathrm{MM}$ is a means of measurement;

STA is a spare tool and accessories;

$\mathrm{ME}$ is a mathematical expectation;

$\mathrm{REM}$ is a radio electronic means;

$\mathrm{RB}$ is a repair body;

$\mathrm{CAD}$ is a conditional algorithm for diagnosing.

\section{NOMENCLATURE}

$L$ is a depth of defect search (dimension of object);

$N_{i}$ is a number of recovered REM type $i=\overline{1, u}$;

$T_{r i}$ is a average recovery time of the REM type $i=\overline{1, u}$; $u$ the number of types of REM that are restored in $\mathrm{RB}$;

$X$ is a parameters of RB affecting the quality of work;

$\Delta$ the range of permissible limits for changing parameters;

$X^{*}$ their significance in solving the problem;

$\rho$ is a mathematical expectation (ME) deviation of the diagnosis with one error in the evaluation of the result of the test;

$\rho_{\max }$ the maximum possible value of this parameter;

$S$ the degree of damage to the ERE (the ratio of the number of defects to the dimension of the object);

$T_{\text {r.perm }}$ is a permissible value of average recovery time of REM;

$R$ is a number of repairers $\mathrm{RB}$;

$t$ is a average run time;

$t_{\text {trb. }}$ is a mean time to troubleshoot;

$C$ the cost of repairing the REM;

$C_{\text {acrep }}$ the acceptable value of the repair cost of the REM;

(C) Romanenko V. P., Sakovich L. N., Ryzhov Y. V., Gnatyuk S. E., Rozum I. Y., 2019

DOI 10.15588/1607-3274-2019-1-2 
$K$ is a average number of checks;

$M$ maximum value of the module for choosing an inhomogeneous conditional algorithm for diagnosing $\mathrm{CAD}$;

$p$ is a the probability of a correct assessment of the results of the verification;

$Z$ is a number of search zones when implementing group band search defects;

$P$ is a probability of correct diagnosis;

$n$ is a number of groups of elements in CAD;

$m$ is a module of choice CAD;

$\mu$ is a number of masters repairing REM;

$c_{i}$ is a the cost of a specialist qualification $\mathrm{i}$ in one hour;

$P_{M}$ is a metrological reliability of MM;

$T_{d}$ is a mean time of diagnosis;

$\tau$ is a inter-verification interval of the MM;

$K_{U}$ is a utilization rate $\mathrm{MM}\left(0,1 \leq K_{U} \leq 0,3\right)$;

$K_{M}$ the share of metrological characteristics uncovered by the integrated control of the MM;

$K_{S}^{*}$ is a statistical estimation of the coefficient of hidden failures $\left(0,1 \leq K_{S} \leq 0.24\right) \mathrm{MM}$;

$T^{*}$ is a statistical estimation of the time-to-day progress of the MM on the refusal;

$K_{Z}$ the number of checks in the search area;

$W$ is a total labor costs for restoration of REM;

$\gamma$ the relative fate of the time of diagnostics from the time of restoration of the efficiency of the REF.

$\lceil K\rceil$ is a rounding the value, $K$ to the whole number;

$\lfloor K\rfloor$ is a integer of the number $K$.

\section{INTRODUCTION}

REM of various uses continuously develop in the direction of improving the satisfaction of user requirements, which leads to their complication, which in turn, worsens the reliability values - the failure rate and the average recovery time $\left(T_{d}\right)$. For example, the number of radio-radio elements of radio stations in the past 30 years has increased by 6,43 times [1], and the required time for their recovery has not changed. It is known that up to $60-80 \%$ of the average recovery time of RES is spent on finding faulty REM and only $20-40 \%$ of this time on their replacement and after-repair of the product [2-8]. Therefore, a promising direction for improving the repair system of REM is to increase the effectiveness of DS, which is understood as a set of interrelated rules, methods, algorithms and tools necessary for performing diagnostics at all stages of the life cycle of REM [9]. Realization of this direction does not require significant economic costs, as the effect is achieved by rational distribution of forces and means of repair body (RB).

The object of study is the diagnostic process of REM, and the subject of study are mathematical models of interaction between specialists of $\mathrm{RB}$ during the restoration of REM with varying degrees of damage.

The purpose of the article is to increase the efficiency of diagnostic provision of radio electronic means at the expense of a reasonable choice of the type of group search of defects.

\section{PROBLEM STATEMENT}

The indicator of the quality of work of specialists the RB capacity - is determined by the number of restored REM sets per unit time

$$
\eta(X)=\frac{\sum_{i=1}^{u} N_{i}(X)}{\sum_{i=1}^{u} T_{r i}(X)} .
$$

The task of upgrading or creating a RB is to achieve maximum bandwidth with given restrictions on parameters

$$
\eta(X)=\max _{x \in \Delta} \eta\left(X^{*}\right)
$$

Values $\eta(X)$ is determined mainly by the average recovery time of the REM, which, in turn, depends on the time of the diagnosis of the object. Thus, the reserve for increasing the efficiency of the work of the team of specialists or RB is to improve the reparability and DS of the REM at the stages of their design (modular design, justification of a set of standard measuring instruments (RB), rational placement of embedded diagnostic tools, the formation of STA for the repair of aggregate method) and operation (technical and technological documentation, training of specialists, implementation of modern achievements of technical diagnostics in the practice of repair).

Thus, the problem arises in explicit form, research and minimization of the function $T_{r}\left(L, S, R, t, t_{t r b}, K, p\right)$ at the given restrictions, determined by the guiding documents, the organizational-staff structure of the RB, the implementation of the repair of the TC by the aggregate method, technological equipment of specialized workplaces:

$$
\begin{gathered}
1 / L \leq S \leq 0,1 ; 1 \leq R \leq 5 ; 0.65 \leq p<1 ; \rho \leq 0.5 ; \\
\rho_{\max } \leq 1 ; T_{r} \leq T_{\text {r.perm. }} ; C \leq C_{\text {ac.rep }} .
\end{gathered}
$$

The problem is solved with assumptions corresponding to the peculiarities of the functioning of the RO: the degree of damage to a technical object is determined with a given probability as a result of defecation: $0.01 \leq S \leq 0.2$ [5];

- the worst case of diagnosing the case of uniform distribution of defects in an object is considered;

- during the diagnosis of new defects in the object does not occur;

- organizational time losses are not taken into account; 
- echnological equipment, MM and sets of ZIP are known to work;

- qualification of specialists corresponds to the post;

- the repair technique is provided with a set of documentation.

The managed variables in the design of DS TC include: $P, P_{M}$, and total number of checks to find defects, which is determined by the values $L, S, R$, type and appearance of the CAD $[8,17]$.

Depending on the operating conditions of the RB, its target function is stationary conditions in providing a given value $T_{\text {r.perm. }}$ at a minimum cost of repair $C$ or in field conditions in minimizing the value of the average recovery time $T_{r}$ with resource constraints [12].

In the practice of repairing REM there are the use of all types of GDS [8, 10-12]:

- independent (GDSI) - at repair of various types of technical objects in universal RB;

- joint (GPAC) - when repairing objects of large dimension with spatially spaced elements;

- zone (GPAZ) - for repairs of the same type REM modular design in specialized RB.

Graphically, CAD are presented in the form of tree logic capabilities (DLM) with an independent and zone GDS or as a group TLP (GTLP) with a common GDS, which are investigated in $[2,4,8,10-12]$.

Problem statement: The choice of the type of GDS with restrictions on the conditions of repair

$$
G D S\left\{\begin{array}{l}
G D S I \\
G D S Z \\
G D S C
\end{array}\right\} \text { at }\left\{\begin{array}{l}
W_{Z}<W_{C}<W_{I} ; \\
T_{r} \leq T_{\text {r.perm. }} ; \\
C \leq C_{\text {ac.rep }} ; \\
0,01<S<0,2 ; \\
1 \leq \mu \leq R ; \\
\rho_{\max } \leq 1 ; \rho \leq 0,5 ; \\
0,6 \leq p<0,999 .
\end{array}\right.
$$

To solve the problem, it is necessary to obtain and investigate the models of interaction between the specialists of RB in the implementation of the GDS, which will, in each case, justify recommendations for the improvement of the DS of the REM. The urgency of this problem increases especially when operating RES in the conditions of remoteness from the supply and repair bases (for example, at Antarctic or space stations), when the restoration of efficiency REM is directly significantly affect the survivability of the operating autonomously isolated groups of specialists or crews of objects.

\section{REVIEW OF THE LITERATURE}

The results of research on certain issues of refinement DS REM are presented in modern scientific papers.

In the works $[2,3,5-7]$ the questions of improvement of the search for defects during the current repair, when
$S=1 / L$. Specific recommendations for the development of CAD to reduce the value are given $T_{r}$.

In the works $[8,10-12]$ the peculiarities of the interaction of the specialists of the RB with the GDS were considered, recommendations for the construction of the CAD were proposed.

The work [4, 13-15] investigated the effect of diagnostic errors on the probability of correct diagnosis, which in the future allowed to substantiate the requirements for MM [16].

The influence of metrological reliability of the MM during the repair of the REM was considered in [17], which allowed to increase the reliability of the calculation of the assessment $T_{r}$.

The procedure for determining the degree of damage to the REM with the given accuracy is formalized in [18].

Thus, the preconditions are created for modeling the GDS process in REM with varying degrees of damage for preliminary analysis of possible variants of DS and justification of the most preferable in each case.

\section{MATERIALS AND METHODS}

The value of the quality indicator of RB is determined mainly by the average time of the reconstruction of the technical object, that is, there is an explicit acquisition task, research and minimization of the function $T_{r}\left(L, S, R, t, t_{t r b}, K, p\right)$ at given restrictions and assumptions.

Taking into account the preliminary analysis of the simulation of the repair process of the REM $[8,10,11]$, which did not take into account the use of all types of GDS, there is a need to create a common model. The essence of the methodology is to use a new model for assessing the quality of diagnostic provision of radioelectronic equipment during repair by a group of specialists. The essence of the model will be to choose the preferred type of GDS on the criterion of minimum time or labor costs and the cost of restoration of efficiency of the RES depending on the permissible limits of changing the parameters of the $\mathrm{CAD}$, taking into account the quantitative assessment of their probabilistic characteristics.

Taking into account the above considerations, the general graph-analytic model of the process (independent, common, zone) of the GDS by a group of specialists is a combination of the set of CAD and the functional dependencies of their parameters and constraints on controlled variables, which allows quantifying and maximizing the production capabilities of RB in the given operating conditions.

Many CAD used in the development of DS of group search of defects are divided depending on the features of the circuit construction of the REM and the degree of their damage in the form $[2,4,8,10-16]$ :

$$
\begin{aligned}
& \text { - incomplete }\left(K_{\min }<K<K_{\max }\right) ; \\
& \text { - perfect }\left(K_{\min }=K=K_{\max }\right) ;
\end{aligned}
$$


- minimal $\left(K_{\max }-K_{\min }=1\right)$;

$-\operatorname{maximum}\left(K_{\min }=1 ; K_{\max }=L-1\right)$.

$K_{\min }-$ minimal , a $K_{\max }$ - the maximum number of inspections in the localization of the defect, and depending on the used MM, qualifications of specialists, diagnostic procedures that are implemented, the form:

- binary $(m=2)$;

- homogeneous $(m=$ const $)$;

- heterogeneous ( $m=$ var $)$.

Inhomogeneous $\mathrm{CAD}$ can be as decreasing as the selection module $m_{j} \geq m_{j+1}$, and with its increase $m_{j} \leq m_{j+1}$, when $j=\overline{1, K-1}$.

Outputs are: $L, R, p-$ from the technical description of the REM, the instructions for technical operation, the circuit construction of the REM, MM, qualifications of specialists; $K, n, m$-implemented diagnostic procedures; $Z ; n ; m$.
Limitations when using the model:

- number of repair personnel;

- regular staff of RB (in stationary conditions);

- average recovery time - no more acceptable;

- application for complex objects consisting of mechanical, radio-electronic and electric elements;

- is designed at the planning and production departments of stationary and field RB and research organizations and enterprises-manufacturers in the modernization of existing and development of advanced objects of REM.

The generalization of the functional dependences of the optimal value of the number of groups of elements in the algorithm, the minimum value of the total number of checks in the search for all defects, the minimum required number of specialists in the group and other indicators DS $[8,10-12]$ allowed to obtain explicitly analytical expressions for quantitative evaluation of indicators the quality of DS GDS of any kind, which are summarized in Table 1, which is a model of GDS.

Table 1 - Model of group search of defects

\begin{tabular}{|c|c|c|c|}
\hline \multirow{2}{*}{ Parameter } & \multicolumn{3}{|c|}{ Browser Type } \\
\hline & independent & bandwidth & joint \\
\hline Type TLP & & & \\
\hline$\left\{\mu, \mathrm{R}, \mathrm{Z}, \mathrm{K}_{\mathrm{Z}}\right\}$ & $\{1,1,1, K\}$ & $\left\{1, R, Z, K_{Z}\right\}$ & $\{\mu, \mu, 1, K\}$ \\
\hline K & $\begin{array}{l}\frac{1-S}{2 S L(m-1)^{2}}\left(\frac{m-1}{1-S}-1\right) \times \\
\times\left(\frac{m-1}{1-S}+m\right)+2(S L-1)+ \\
+S L \log _{m} \frac{1-S}{S(m-1)}\end{array}$ & $Z\left(1+K_{Z}\right)+S L / Z$ & $\begin{array}{l}S L\left(1+\log _{\mu+1} \frac{L}{n}\right)+ \\
+\frac{n-\mu-1}{\mu}\end{array}$ \\
\hline$K_{Z}$ & - & $\begin{array}{l}\frac{1-S}{2 S L(m-1)^{2}}\left(\frac{m-1}{1-S}-1\right)\left(\frac{m-1}{1-S}+m\right)+ \\
+2\left(\frac{S L}{Z}-1\right)+\frac{S L}{Z} \log _{m} \frac{1-S}{S(m-1)}\end{array}$ & - \\
\hline$n$ & & $/ Z(1-S)$ & $\mu S L /(1-S) \ln (\mu+1)$ \\
\hline$P$ & & $Z K_{Z} / S L$ & $P_{M} p^{\mu\left(1+\log _{\mu+1}(L / n)\right)}$ \\
\hline$T_{B}$ & & $\left(\mu t K+S L t_{y}\right) / P R$ & \\
\hline$W$ & & $\left(\mu t K+S L t_{y}\right) / P$ & \\
\hline$C$ & & {$\left[\left(\mu t K+S L t_{y}\right) / P \sum_{i=1}^{R} c_{i}\right.$} & \\
\hline
\end{tabular}


Taking into account the above considerations, the general model of the process (independent, common, zone) GDS is a set of CAD that are implemented by a group of specialists and the functional dependencies of their parameters and constraints on controlled variables, which allows quantifying and maximizing the production capabilities of RB in the given operating conditions. Analytical expressions for quantitative estimation of values $\rho$ i $\rho_{\max }$ for different types of GDS and CAD data [15] are summarized in Table 2 for GDSC and Table 3 for GDSI and GDSZ.

\section{MODEL GDS}

\section{Incoming data}

\begin{tabular}{|l|}
\multicolumn{1}{c|}{ Analysis } \\
- Requirements \\
$T_{\text {r.porm }} ;$ \\
- Construction FEM; \\
- Terms repairs
\end{tabular}

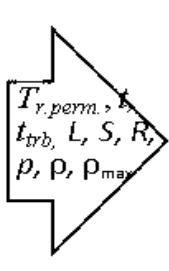

The set of CAD plunal and functional dependencies of their parameters on controlled variables, which allows to quatify and moximize the production capabilities of $R B$ in the given operating conditions:

$\boldsymbol{K}, \boldsymbol{n}, \boldsymbol{m}, \boldsymbol{Z}, \boldsymbol{P}$
Output data

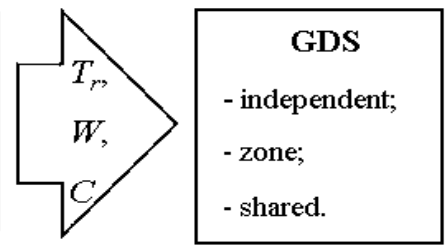

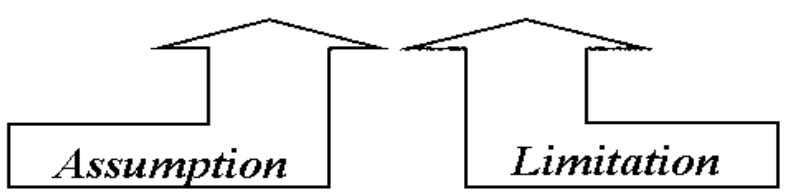

Figure 1 - Structure of the model of group search of multiple defects

Table 2 - Quantitative evaluation of the mathematical expectation of a defect of a diagnosis with one specialist mistake and a joint group defect finding

\begin{tabular}{|c|c|c|}
\hline $\begin{array}{l}\text { Form Group } \\
\text { CAD }\end{array}$ & $\rho$ & $\rho_{\max }$ \\
\hline Perfect & $0,5[K+(L-1) / \mu] g p^{\mu K-1}$ & {$[(L-1) / \mu] g p^{\mu K-1}$} \\
\hline Incomplete & $\frac{0,5 g}{\mu p L} \sum_{i=1}^{K_{\max }} l_{i}\left[(\mu+1)^{i}+i \mu-1\right] p^{i \mu}$ & $\frac{g}{\mu L} \sum_{i=1}^{K_{\max }} l_{i}\left((\mu+1)^{i}-1\right) p^{i \mu-1}$ \\
\hline \multirow[b]{2}{*}{ Minimum } & \multirow{2}{*}{$\begin{array}{l}\left(g p^{\mu\lceil K\rceil-1} / 2 L \mu^{2}\right)\left[\left((\mu+1)^{\lceil K\rceil}-L\right) \times\right. \\
\times\left((\mu+1)^{\lceil K\rceil-1}+(\lceil K\rceil-1) \mu-1\right) \div \\
\div p^{\mu}+(\mu+1)\left(L-(\mu+1)^{\lceil K\rceil-1}\right) \times \\
\left.\times\left((\mu+1)^{\lceil K\rceil}+\lceil K\rceil \mu-1\right)\right]\end{array}$} & $\begin{array}{l}\left((\mu+1)^{\lceil K\rceil}-1\right) g p^{\mu\lceil K\rceil-1} / \mu \text { for } \\
\mu^{\lceil K\rceil-2}(2 \mu+1) \leq L \leq(\mu+1)^{K}\end{array}$ \\
\hline & & $\begin{array}{l}\frac{g p^{\mu\lceil K\rceil-1}}{\mu^{2}(\mu+1)^{|K|-2}}\left[\left((\mu+1)^{\lceil K\rceil}-1\right)\left(L-(\mu+1)^{\lceil K\rceil-1}\right) p+\right. \\
\left.+\left((\mu+1)^{\lceil K\rceil-1}-1\right)\left((\mu+1)^{\lceil K\rceil-2}(2 \mu+1)-L\right)\right] \\
\text { for }(\mu+1)^{\lceil K\rceil-1} \leq L \leq \mu \mu^{\lceil K\rceil-2}(2 \mu+1)\end{array}$ \\
\hline Maximum & $\begin{array}{l}\frac{0,5 g}{\mu p L}\left[(\mu+1) p^{K_{\max }}\left((\mu+1)^{K_{\max }}+L-2\right)+\right. \\
\left.+\mu \sum_{i=1}^{K_{\max }-1}\left((\mu+1)^{i}+i \mu-1\right) p^{i}\right]\end{array}$ & $(L-\mu) g p^{\mu K_{\max }-1}$ \\
\hline
\end{tabular}


Table 3 - Quantitative estimation of the mathematical expectation of deviation of the diagnosis $(\rho)$ with one specialist mistake and the search for defects in the CAD

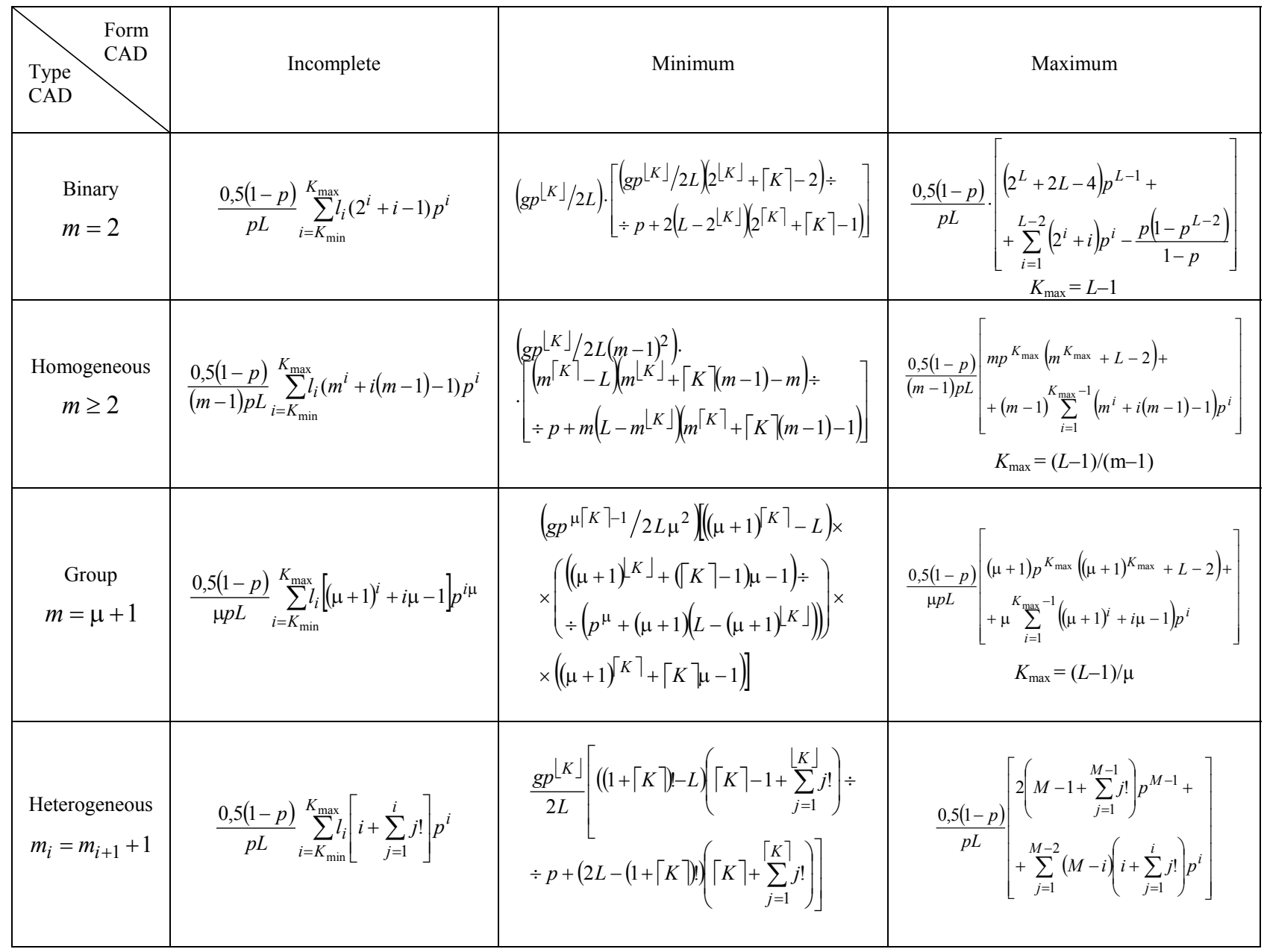

When using Table 3 for the estimation of GDS indices by algorithms of the minimum and maximum form in the calculation expressions instead of $L$ should be substituted $L / Z$, but instead $K$ substitute $K_{z}$.

Functional dependencies of Table 2 and 3 are valid for the current repair of REM, in the presence of multiple defects they are used to assess the values $\rho$ i $\rho_{\max }$ in each group of elements, since in the implementation of the truncated search procedure in the CAD at a uniform distribution of defects not more than one element in the group is defective $[10-12,15]$.

Value $\mu, R, Z$ are selected based on the conditions of repair and design REMDescription of the implementation algorithm:

- requirements to DS REM;

- receipt and analysis of the output data;

- establishment of restrictions and assumptions based on the conditions of repair;

- substantiation of the criterion of choice of DS REM;

- assessment of quality indicators of DS REM using a new mathematical model;
- the choice of the optimal variant of the development of DS REM based on the results of simulation;

- development of the CAD of the chosen version of the GDS;

- assessment of the effectiveness of CAD GDS.

In accordance with the requirements of transforming the CAD into a diagnostic program and experimental verification, otherwise, the change of output data (qualifications of performers, process equipment, MM, depth of defects search).

\section{EXPERIMENTS}

The adequacy of the model is the ability to describe the output parameters with a relative error of not more than a given value [19]. The adequacy of the model is checked on the example of the development of the DS of the receiving path of the tropospheric communication station P-423 provided that the two wizards are jointly searched for defects with the following output data: $L=51, \quad S=0.01 ; \quad p=0.995 ; \quad T_{\text {r.perm. }} \leq 20 \mathrm{~min}$; $t=3 \min , t_{t r b}=5 \min ; m=2 ; \mu=2$ [14]. 


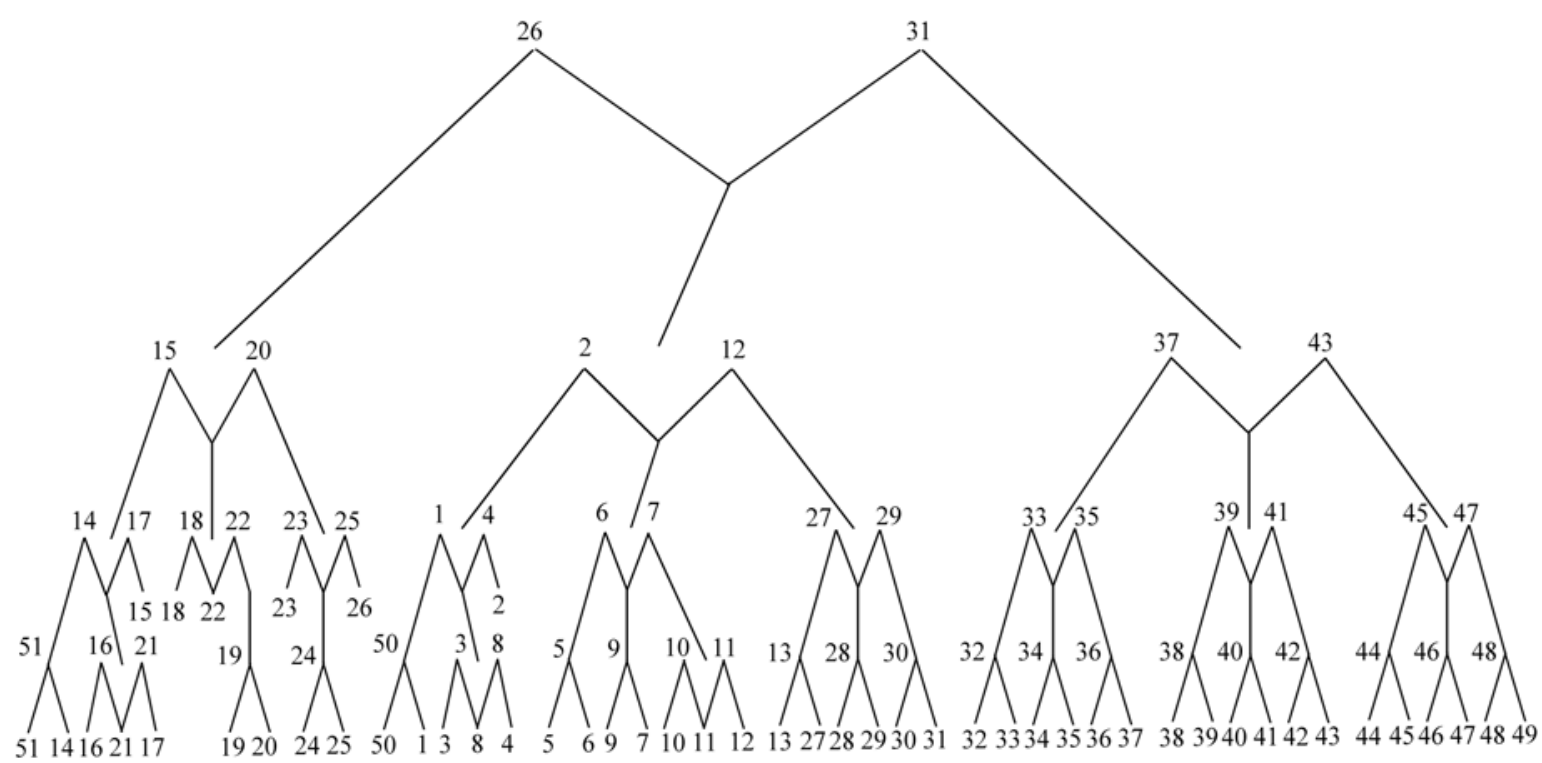

Figure 2 - Conditional algorithm of parallel (common) defect search in the receiving path of P-423

The results of testing the adequacy of the model are summarized in Table 4, the analysis of which shows that the relative error of the results of calculations of the average recovery time $\delta T_{r} \leq 3.35 \%$, and labor costs $\delta W \leq 5.0 \%$, this confirms the feasibility of using the model to evaluate the possibility of applying the type of GDS.

Table 4 - Results of the check of adequacy of the model of group search of defects

\begin{tabular}{|c|c|c|c|c|}
\hline \multicolumn{2}{|c|}{ Type of search } & $P$ & $T_{r} \cdot \min$ & $W$. pers. hours \\
\hline \multicolumn{2}{|c|}{ GDSC [14] } & 0.931 & 17.9 & 0.6 \\
\hline \multirow{3}{*}{ 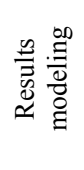 } & $G D S I$ & 0.944 & 24.0 & 0.4 \\
\hline & GDSZ & 0.944 & 20.3 & 0.67 \\
\hline & $G D S C$ & 0.911 & 17.3 & 0.57 \\
\hline
\end{tabular}

The discrepancy between the results of the simulation (the presence of an error) and the quality of the DS is due to the fact that the model is oriented on the use of a homogeneous algorithm, but in reality, depending on the features of a particular object, the use of heterogeneous algorithms is possible. In the example that is considered independent and zone search does not meet the conditions of recovery $T_{r}>T_{\text {r.perm. }}$. In addition, the design of the object practically does not allow to implement a zone search, therefore, it is advisable to use the DS with GDSC (Fig. 2).

\section{RESULTS}

The obtained model allows comparing the effectiveness of different types of implementation of the GDS. In Table 5 shows the dependence of labor costs on the repair of one set of REM from the depth of the defect (dimension of the object) $L$ and the form of the GDS, where the physical sense has only points, and dotted lines reflect the tendencies of changing the parameters. There are also obvious advantages of group band search of defects, which minimizes both time and labor costs for repairs.

Table 5 - Dependence of labor (W, pers. hours) and the average recovery time $(\mathrm{Tr}, \mathrm{h})$ selection of the depth of the defect search $(L)$ and type in the GDS at $S=0.02 ; m=2 ; p=0.995$

\begin{tabular}{|c|c|c|c|c|c|}
\hline \multirow{2}{*}{$G D S$} & $L$ & 100 & 500 & 1000 & 2000 \\
\hline $\begin{array}{c}G D S I \\
\mu=1\end{array}$ & $\mathrm{~W}$ & 1.6 & 10.1 & 16.8 & 32.1 \\
\cline { 2 - 6 } & Тв & 2.2 & 7.9 & 16.9 & 31.8 \\
\hline \multirow{2}{*}{$G D S Z$} & $\mathrm{~W}$ & 2.1 & 9.7 & 22.2 & 43.1 \\
\cline { 2 - 6 } & Тв & 1.8 & 5.1 & 9.7 & 20.0 \\
\hline \multirow{2}{*}{$\begin{array}{c}G D S C \\
\mu=4\end{array}$} & $\mathrm{~W}$ & 1.5 & 10.2 & 17.1 & 34.8 \\
\cline { 2 - 6 } & Тв & 1.1 & 2.3 & 3.9 & 9.1 \\
\hline
\end{tabular}

Similar results are obtained in the study of the dependence of labor costs on repair of one set PEM on the degree of its damage $\mathrm{S}$ and the type of GPA (Table 6) for $L=1000, m=2, p=0.995$.

Table 6 - Dependence of labor (W, pers. hours) and the average recovery time $(\mathrm{Tr}, \mathrm{h})$ selection of the degree of the defect search $(S)$ and type in the GDS at $L=1000 ; m=2$; $p=0.995$

\begin{tabular}{|c|c|c|c|}
\hline \multirow{2}{*}{$G D S$} & $S$ & 0,02 & 0,04 \\
\hline \multirow{2}{*}{$G D S I$} & $\mathrm{~W}$ & 16,8 & 29,0 \\
\cline { 2 - 4 } & $\mathrm{Tr}$ & 16,9 & 23,8 \\
\hline \multirow{2}{*}{$G D S Z$} & $\mathrm{~W}$ & 22,2 & 37,1 \\
\cline { 2 - 4 } & $\mathrm{Tr}$ & 9,7 & 18,2 \\
\hline \multirow{2}{*}{$G D S C$} & $\mathrm{~W}$ & 17,1 & 30,0 \\
\cline { 2 - 4 } & $\mathrm{Tr}$ & 3,9 & 8,2 \\
\hline
\end{tabular}

(C) Romanenko V. P., Sakovich L. N., Ryzhov Y. V., Gnatyuk S. E., Rozum I. Y., 2019 DOI 10.15588/1607-3274-2019-1-2 
It is understood, that higher qualification of the specialist implies shorter time needed for the test and troubleshooting. However, consequently, it increases expenses for his salary. As an example, let's consider the influence of qualification of executors on time and cost of repair for different types of GDS under the same conditions: $L=1000, S=0.04 ; p=0.995 ; Z=20 ; m=2 ; R=4$; $\mu=2$, but with low qualifications $c=5 U A H /$ hour $, t=3 \mathrm{~min}, t_{y}=5 \mathrm{~min}$, but with high qualifications $\quad c=10 \mathrm{UAH} / \mathrm{hour}, \quad t=1.5 \mathrm{~min}$; $t_{y}=2.5 \mathrm{~min}$. Results of calculations according to the Table. 1 are shown in Fig. 3, where the line is represented by a stroke - corresponds to a low qualification, and without a stroke - a highly skilled performer. As before, the best indicators have a group band defect search.

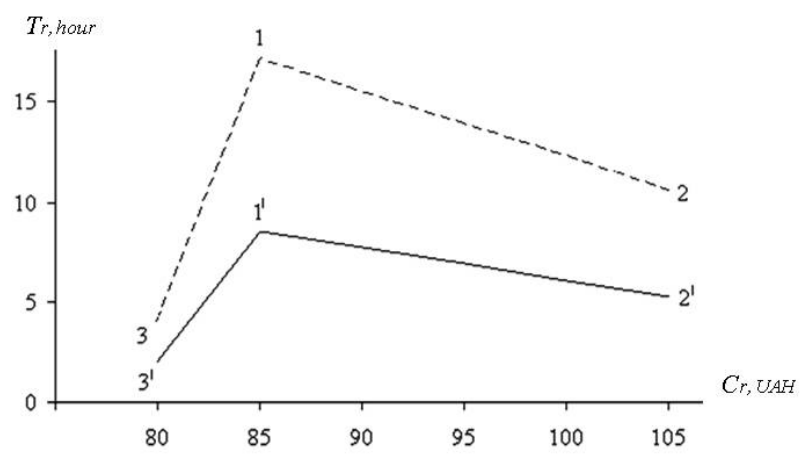

Figure 3 - Depending on the time and cost of repair from the skill of the performers and the type of group search of defects

In all cases, professional development leads to a reduction in the time of recovery by increasing the intensity of labor, the use of effective CAD (heterogeneous with the module of choice of more than two).

Consider the effect of reducing the average diagnostic time $T_{d}$ at current repairs of REM for the RB throughput. In the simplest case $N_{i}=1 ; n=1, P \approx 1, t_{t r b}=$ const we will get $T_{r}=T_{d}+t_{t r b}$. Due to the improvement of the DS the value decreases $T_{d}$, which leads to a decrease in the average recovery time of the average recovery time with increasing RB throughput. Denote the relative reduction in the time of diagnosis $\gamma=T_{d} / T_{r}$, in this case we will receive $T_{r}=t_{t r b} /(1-\gamma)$ i $\eta(x)=1 / T_{r}=(1-\gamma) / t_{r}$ (Fig. 4).

His analysis shows that, for example, reducing the time of diagnosis of RES from $80 \%$ to $60 \%$ of the value $T_{r}$ increases RB throughput twice. The effect is achieved without additional expenses for the equipment of the $\mathrm{PB}$ due to the improvement of the DS.

In practice of repair all types of group search find:

- independent - when repairing different types of REFs on universal workplaces;

- common - when repairing objects of large dimension with spatially spaced elements;

- zone - for repair of the same type REZ modular design in specialized work places PO.

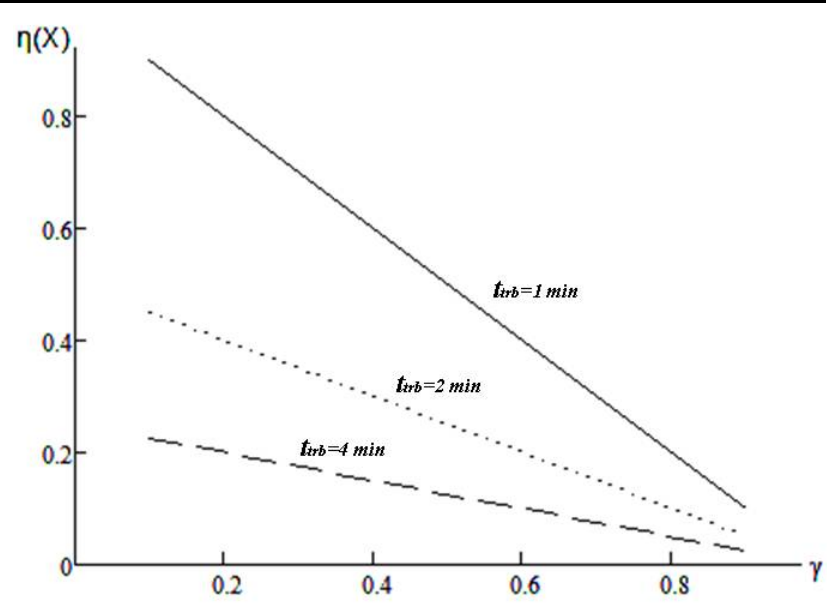

Figure 4 - Dependence of RO throughput improvement of the DZ and the time of troubleshooting

The simulation results allow to quantify the quality of the DS of different types of GDS and depending on the task of optimizing the number of repairers and CAD parameters.

\section{DISCUSSION}

Considered the possibility of increasing the efficiency of the RB REM by improving their DS, namely - by the previous modeling to establish the most appropriate for each case from the GDS taking into account the design of the REF, the degree of their damage and the conditions of recovery of disability.

Thus, the use of the methodology allows the development of a specific algorithm for defect detection to quantify the possible indicators of the quality of the diagnostic process.

The effect of using the methodology is to reduce labor costs for the development of DS due to the fact that for choosing the type of GDS there is no need to develop a search algorithm for each of them, as it is possible to evaluate in advance with the necessary accuracy indicators of their quality and choose the most preferred by the given criterion.

The simulation results allow us to quantify the quality of the DS of different types of GDS and, depending on the task of optimizing the number of repairers and parameters of the CAD. In the article for the first time various types of GDS are considered in a complex way with a quantitative estimation of the efficiency of their use. The results obtained should be used in the methodology for developing diagnostic programs for the GDS during the repair of the REM by the crews in the field, as well as during the development of their metrological support with a minimum cost of traffic accidents.

These studies are a continuation of work to improve the DS of modern REM for reducing labor costs and the time of their recovery in conditions of autonomous use at remote locations from the supply and repair.

In the future, it is necessary to optimize the organizational and staff structure of the PB of its material and technical base by the chosen criterion: average recovery time, minimum labor costs or the cost of single repair of the REM.

(C) Romanenko V. P., Sakovich L. N., Ryzhov Y. V., Gnatyuk S. E., Rozum I. Y., 2019 DOI 10.15588/1607-3274-2019-1-2 


\section{CONCLUSIONS}

A comparative analysis of possible types of GDS during the restoration of REM is performed and the methodology was obtained on the basis of a generalized graphical model of this process. The probabilistic time and cost indicators of the quality of the functioning of the PB REM are estimated in quantitative terms.

The analytical estimation of the MS of the diagnosis from the true one in the presence of one error of the expert in the evaluation of the result of the test was obtained.

Scientific novelty of the methodology consists in obtaining common analytical expressions for quantitative estimation of the quality indices of any type of GDS.

In addition, for the first time, the verification of the possibility of using all types of GDS to perform repairs by the aggregate method due to the quantitative assessment of the diagnosis of a diagnosis with a diagnosis mistake.

For the first time, various types of group search with a quantitative assessment of the effectiveness of their use are considered in a complex way.

The obtained results should be used in the development of diagnostic support for group search of defects in the repair of REM crews and the elimination of accidental damage in field conditions

\section{ACKNOWLEDGEMENTS}

This work was supported by the Hetman Petro Sahaidachnyi National Army Academy (Lviv, Ukraine).

\section{REFERENCES}

1. Yerohin V. F., Raevs'kij V. M. Prognozuvannja osnovnih harakteristik perspektivnih radiostancij silovih struktur, Zv'jazok, 2005, No. 3, pp. 61-64.

2. Kononov V., Ryzhov Ye., Sakovych L. Dependence of parameters of repair of military communication means on the quality of metrological support, Advanced Information Systems, 2018, Vol. 2, No. 1, pp. 91-95. DOI: https://doi.org/10.20998/2522-9052.2018.1.17.

3. Czichos H. Handbook of Technical Diagnostics: Fundamentals and Application to Structures and Systems, 2013, P. 559. DOI: https://doi.org/10.1007/978-3-64225850-3.

4. Ksenz S. P., Poltarzhickij M. I., Alekseev S. P., Mineev V. V. Bor'ba s diagnosticheskimi oshibkami pri tehnicheskom obsluzhivanii i remonte sistem upravlenija svjazi i navigacii. Sanktpiterburg, VAS, 2010, 240 p.

5. Pasini G., Lorenzo P., Tinarelli Roberto Study of the Accuracy Requirements of the Instrumentation for Efficiency Measurements in Power Conversion Systems, IEEE Transactions on Instrumentation and Measurement, 03 July, 2013, Vol. 62, Issue 8, P. 2154-2160. DOI: http://dx.doi.org/10.1109/TIM.2013.2264864.
6. Jack R., Nicholas P. E. Mastering the Maintenance Process, IMC-2004 The 19th International Maintenance Conference.

7. Romanovich Zh. A., Skrjabin V. A., Fadeev V. P., Cypin B. V. Diagnostirovanie, remont i tehnicheskoe obsluzhivanie sistem upravlenija bytovyh mashin i priborov. Moscow, Dashkov i K, 2014, 316 p.

8. Ryzhov Ye., Sakovych L., Vankevych P., Yakovlev M., Nastishin Y. Optimization of requirements for measuring instruments at metrological service of communication tools. Measurement, Journal of the International Measurement Confederetion, Volume 123, (July 2018), pp. 19-25. DOI: https://doi.org/10.1016/j.measurement.2018.03.055.

9. Timofiejczuk A. Advances in Technical Diagnostics: Proceedings of the 6th International Congress on Technical Diagnostic, ICDT 2016, 12-16 September 2016, Gliwice, Poland, $521 \mathrm{p}$

10. Ryzhakov V. A., Sakovich L. N. Gruppovoj zonnyj poisk kratnyh defektov pri remonte tehniki svjazi, Zv'jazok, 2005, No. 1, pp. 57-60.

11. Sakovich L. N., Ryzhakov V. A. Sovmestnyj gruppovoj poisk kratnyh defektov pri remonte tehniki svjazi, Zv'jazok, 2005, No. 2, pp. 59-62.

12. Halderman J. Diagnosis and Troubleshooting of Automotive Electrical, Electronic, and Computer Systems (6th Edition) (Pearson Automotive Series), 2014, 720 p.

13. Bell D. Electronic Devices and Circuits. Oxford University Press, Fifth Edition, 2008, 1092 p.

14. Hughes J. Practical Electronics, Components and Techniques. Publisher, O’Reilly Media, Inc., 2015, 560 p.

15. Sakovich L. N., Vansovich Ju. P. Kolichestvennaja ocenka dostovernosti diagnostirovanija pri ustranenii avarijnyh povrezhdenij tehniki svjazi, Zv'jazok, 2010, No. 2, pp. 4749 .

16. Ryzhov E. V., Sakovich L. M. Metod obrruntuvannja minimal'no pripustimogo znachennja jmovirnosti ocinki rezul'tatu perevirki parametriv. Visnik Nacional'nogo tehnichnogo universitetu Ukraïni "Kï̈vs'kij politehnichnij institut”, Serija PRILADOBUDUVANNJa, 2017, Vip. 54(2). pp. 96-106. DOI: https://doi.org/10.20535/1970.54(2).2017.119562.

17. Kononov V. B., Vodolozhko O. V., Koval' O. V. Osnovi ekspluataciï zasobiv vimirjuval'noï tehniki vijs'kovogo priznachennja $\mathrm{v}$ umovah provedennja ATO, navch. posib. Harkiv, HNUPS, 2017, 288 p.

18. Sakovich L. M., Ryzhov E. V. Metodika predvaritel'noj defektacii apparatnyh svjazi s mnozhestvennymi povrezhdenijami v polevyh uslovijah. Visnik Nacional'nogo tehnichnogo universitetu Ukraïni "Kï̈vs'kij politehnichnij institut". Serija PRILADOBUDUVANNJa, 2017, Vip. 53(1), pp. 32-38. http://dx.doi.org/10.20535/1970.53(1).2017.106580.

19. Khandpur R. S. Troubleshooting electronic equipment: Includes Repair And Maintenance. Second Edition, McGraw-Hill Education (India) Private Limited, 2003, $417 \mathrm{p}$.

Received 08.08.2018. Accepted 24.01.2019. 


\section{МЕТОДИКА ОБГРУНТУВАННЯ ВИДУ І ОЦІНКИ ЯКОСТІ ГРУПОВОГО ПОШУКУ ДЕФЕКТІВ ПРИ РЕМОНТІ РАДІОЕЛЕКТРОННИХ ЗАСОБІВ}

Романенко В. П. - канд. техн. наук, завідувач спеціальної кафедри № 4 Інституту спеціального зв’язку та захисту інформації КПІ імені Ігоря Сікорського, м. Київ, Україна.

Сакович Л. М. - канд. техн. наук, доцент, доцент спеціальної кафедри № 4 Інституту спеціального зв’язку та захисту інформації КПІ імені Ігоря Сікорського, м. Київ, Україна.

Рижов С. В. - канд. техн. наук, старший науковий співробітник науково-дослідної лабораторії Наукового центру Сухопутних військ Національної академії сухопутних військ імені гетьмана Петра Сагайдачного, м. Львів, Україна.

Гнатюк С. С. - канд. техн. наук, начальник відділу управління Департаменту розвитку електронних комунікацій Державної служби спеціального зв'язку та захисту інформації, м. Київ, Україна.

Розум І. Ю. - канд. військ. наук, старший науковий співробітник Національного університету оборони України імені Івана Черняховського, м. Київ, Україна.

Актуальність. Радіоелектронні засоби безперервно ускладнюються, що затрудняє процес відновлення їх працездатності, коли на діагностування витрачають найбільші працевитрати і час. Тому перспективним напрямком підвищення ефективності відновлення сучасних радіоелектронних засобів є удосконалення діагностичного забезпечення. Метою статті є підвищення ефективності діагностичного забезпечення радіоелектронних засобів за рахунок обгрунтованого вибору виду групового пошуку дефектів

Метод. В роботі виконано аналітичні дослідження умовних алгоритмів діагностування 3 використанням методів теорії графів, теорії ймовірностей і теорії дискретного пошуку - наукової дисципліни, яка вивчає процес діагностування при відновленні працездатності складних технічних об'єктів з різним ступенем пошкодження за допомогою дослідження і оптимізації процедур і алгоритмів виявлення апріорно-невідомої кількості елементів із заданими властивостями $з$ кінцевої структурно-зв’язної множини за деяким критерієм.

Результати. Отримано методику вибору виду алгоритму групового пошуку дефектів при заданих обмеженнях та допущеннях по критерію мінімуму трудовитрат на основі узагальнення графо-аналітичної моделі групового пошуку дефектів 3 кількісною оцінкою ймовірнісних, часових $\mathrm{i}$ вартісних показників якості процесу діагностування радіоелектронних засобів з різним ступенем пошкодження, що дозволяє заздалегідь обгрунтувати найбільш доцільний алгоритм групового пошуку дефектів для використання під час розробки діагностичного забезпечення сучасних радіоелектронних засобів.

Висновки. Вперше комплексно розглянуті різні види групового пошуку дефектів 3 кількісною оцінкою ефективності їх використання залежно від особливостей радіоелектронних засобів і умов відновлення їх працездатності.

КЛЮЧОВІ СЛОВА: радіоелектронні засоби, груповий пошук дефектів, відновлення працездатності, діагностичне забезпечення.

УДК 621.396 .6

\section{МЕТОДИКА ОБОСНОВАНИЯ ВИДА И ОЦЕНКИ КАЧЕСТВА ГРУППОВОГО ПОИСКА ДЕФЕКТОВ ПРИ РЕМОНТЕ РАДИОЭЛЕКТРОННЫХ СРЕДСТВ}

Романенко В. П. - канд. техн. наук, заведующий специальной кафедры № 4 Института специальной связи и защиты информации КПИ имени Игоря Сикорского, г. Киев, Украина.

Сакович Л. М. - канд. техн. наук, доцент, доцент специальной кафедры № 4 Института специальной связи и защиты информации КПИ имени Игоря Сикорского, г. Киев, Украина

Рыжов Е. В. - канд. техн. наук, старший научный сотрудник научно-исследовательской лаборатории Научного центра Сухопутных войск Национальной академии сухопутных войск имени гетмана Петра Сагайдачного, г. Львов, Украина

Гнатюк С. Е. - канд. техн. наук, начальник отдела управления Департамента развития электронных коммуникаций Государственной службы специальной связи и защиты информации, г. Киев, Украина.

Розум И. Ю. - канд. воен. наук, старший научный сотрудник Национального университета обороны Украины имени Ивана Черняховского, г. Киев, Украина.

\section{АННОТАЦИЯ}

Актуальность. Радиоэлектронные средства непрерывно усложняются, что затрудняет процесс восстановления их работоспособности, когда на диагностирование тратят большие трудозатраты и время. Поэтому перспективным направлением повышения эффективности восстановления современных радиоэлектронных средств является совершенствование диагностического обеспечения. Целью статьи является повышение эффективности диагностического обеспечения радиоэлектронных средств за счет обоснованного выбора вида группового поиска дефектов.

Метод. В работе выполнено аналитические исследования условных алгоритмов диагностирования с использованием методов теории графов, теории вероятностей и теории дискретного поиска - научной дисциплины, изучающей процесс диагностирования при восстановлении работоспособности сложных технических объектов с разной степенью повреждения с помощью исследования и оптимизации процедур и алгоритмов обнаружения априорно-неведомого количества элементов с заданными свойствами из конечного структурно-связного множества по некоторому критерию. 
Результаты. Получено методику выбора вида алгоритма группового поиска дефектов при заданных ограничениях и допущениях по критерию минимума трудозатрат на основе обобщения графо-аналитической модели группового поиска дефектов с количественной оценкой вероятностных, временных и стоимостных показателей качества процесса диагностирования радиоэлектронных средств с разной степенью повреждения, что позволяет заранее обосновать наиболее целесообразный метод группового поиска дефектов для использования при разработке диагностического обеспечения современных радиоэлектронних средств.

Выводы. Впервые комплексно рассмотрены различные виды группового поиска дефектов с количественной оценкой эффективности их использования в зависимости от особенностей радиоэлектронных средств и условий восстановления их работоспособности.

КЛЮЧЕВЫЕ СЛОВА: радиоэлектронные средства, групповой поиск дефектов, восстановления работоспособности, диагностическое обеспечение.

\section{ЛІТЕРАТУРА / ЛИТЕРАТУРА}

1. Єрохін В. Ф. Прогнозування основних характеристик перспективних радіостанцій силових структур / В. Ф. Срохін, В. М. Раєвський // Зв’язок. - 2005. - № 3. C. 61-64.

2. Kononov V. Dependence of parameters of repair of military communication means on the quality of metrological support / V. Kononov, Ye. Ryzhov, L. Sakovych // Advanced Information Systems. - 2018. - Vol. 2, No. 1. P. 91-95. DOI: https://doi.org/10.20998/25229052.2018.1.17.

3. Czichos H. Handbook of Technical Diagnostics: Fundamentals and Application to Structures and Systems / H. Czichos. - 2013. - P. 559. DOI: https://doi.org/10.1007/978-3-642-25850-3.

4. Борьба с диагностическими ошибками при техническом обслуживании и ремонте систем управления связи и навигации / [Ксенз С. П., Полтаржицкий М. И., Алексеев С. П., Минеев В. В.]. - СПб. : ВАС, 2010. $240 \mathrm{c}$.

5. Pasini G. Study of the Accuracy Requirements of the Instrumentation for Efficiency Measurements in Power Conversion Systems / G. Pasini, L. Peretto, Tinarelli R. // IEEE Transactions on Instrumentation and Measurement, 03 July. - 2013. - Vol. 62, Issue 8. - P. 2154-2160. DOI: http://dx.doi.org/10.1109/TIM.2013.2264864.

6. Jack R. Mastering the Maintenance Process / R. Jack, P. E. Nicholas // IMC-2004 The 19th International Maintenance Conference.

7. Диагностирование, ремонт и техническое обслуживание систем управления бытовых машин и приборов / [Ж. А. Романович, $\quad$ В. А. Скрябин, $\quad$ В. П. Фадеев, Б. В. Цыпин]. - М. : Дашков и К, 2014. - 316 с.

8. Optimization of requirements for measuring instruments at metrological service of communication tools / [Ryzhov Ye., Sakovych Lev, Vankevych Petro et al.] // Measurement. Journal of the International Measurement Confederetion. Volume 123 (July 2018). - P. 19-25. DOI: https://doi.org/10.1016/j.measurement.2018.03.055.

9. Timofiejczuk A. Advances in Technical Diagnostics: Proceedings of the 6th International Congress on Technical / A. Timofiejczuk // Diagnostic, ICDT2016, 12-16 September. - 2016, Gliwice, Poland. - 521 p.
10. Рыжаков В. А. Групповой зонный поиск кратных дефектов при ремонте техники связи / В. А. Рыжаков, Л. Н. Сакович // Зв'язок. - 2005. - № 1. - С. 57-60.

11. Сакович Л. Н. Совместный групповой поиск кратных дефектов при ремонте техники связи / Л. Н. Сакович, В. А. Рыжаков // Зв'язок. - 2005. - № 2. - С. 59-62.

12. Halderman J. Diagnosis and Troubleshooting of Automotive Electrical // Electronic, and Computer Systems (6th Edition) (Pearson Automotive Series). - 2014. - 720 p.

13. David Bell. Electronic Devices and Circuits / Bell David. Oxford University Press, Fifth Edition, 2008. - 1092 p.

14. Hughes J. Practical Electronics: Components and Techniques / John M. Hughes. - Publisher : O’Reilly Media, Inc., 2015. $-560 \mathrm{p}$.

15. Рижов Є. В. Дослідження показників якості групового пошуку дефектів під час поточного ремонту військової техніки зв'язку / Є. В. Рижов, Л. М. Сакович // Збірник наукових праць Військової академії (м. Одеса). - 2017. № 2(8). - C. $82-88$.

16. Рижов Є. В. Метод обгрунтування мінімально припустимого значення ймовірності оцінки результату перевірки параметрів / С. В. Рижов, Л. М. Сакович // Вісник Національного технічного університету України «Київський політехнічний інститут». Серія ПРИЛАДОБУДУВАННЯ. - 2017. - Вип. 54 (2). - С. 96106. DOI: https://doi.org/10.20535/1970.54(2).2017.119562.

17. Основи експлуатації засобів вимірювальної техніки військового призначення в умовах проведення АТО: навч. посіб. / В. Б. Кононов, О. В. Водоложко, О. В. Коваль та ін. - Х. : ХНУПС, 2017. -288 с.

18. Сакович Л. М. Методика предварительной дефектации аппаратных связи с множественными повреждениями в полевых условиях / Л. М. Сакович, Е. В. Рыжов // Вісник Національного технічного університету України «Київський політехнічний інститут». Серія ПРИЛАДОБУДУВАННЯ. - 2017. - Вип. 53(1). - С. 3238. DOI: http://dx.doi.org/10.20535/1970.53(1).2017.106580.

19. Khandpur R. S. Troubleshooting electronic equipment: Includes Repair And Maintenance / R. S. Khandpur. Second Edition : McGraw-Hill Education (India) Private Limited, 2003. $-417 p$ 